\title{
PREVALENCE OF ALUMINUM PHOSPHIDE INTOXICATION AMONGST VICTIMS OF POISONING - FORENSIC MEDICINE AND TOXICOLOGY REGISTRY DATA
}

\author{
Beenish Malik, Khalid Saleem, Hakim Khan Afridi, Rabia Khan, Masud Uz Zaman \\ Department of Forensic Medicine, Khyber Medical College, Peshawar - Pakistan
}

\begin{abstract}
Objectives: To study the prevalence of aluminum phosphide intoxication reported to Forensic Medicine and Toxicology Department.

Material and Methods: Retrospective chart review was conducted on the victims of aluminum phosphide poisoning out of the total autopsies conducted at the Department of Forensic Medicine and Toxicology, Khyber Medical College, Peshawar, from January 2019 to December 2019. The cases were identified on the basis of postmortem findings, laboratory results and the police inquest report. SPSS 20.0 was used as a statistical tool for the study.

Results: A total of 940 cases of poisoning were received, out of which 99 were of aluminum phosphide intoxication making a percentage of $10.5 \%$. Amongst these 70 were females and 29 were males. The most commonly affected age group is 11-20 years among females and 21-30 years among males and intoxication was more common in rural than in urban areas.

Conclusion: Aluminum phosphide (wheat pills) is one of the most commonly used substance for poisoning among young people. More prevalent in rural areas, due to easy availability with a maximum number of cases received in the month of December.
\end{abstract}

Keywords: Postmortem, Toxicology, Intoxication, Aluminum Phosphide

This article may be cited as: Malik B, Saleem K, Afridi HK, Khan R, Zaman MU. Prevalence Of Aluminum Phosphide Intoxication Amongst Victims Of Poisoning - Forensic Medicine And Toxicology Registry Data. J Med Sci 2021 April;29(2):75-78

\section{INTRODUCTION}

Metal phosphides such as aluminum phosphide is a potent insecticide. Aluminum phosphide (ALP) and zinc phosphide are highly effective fumigant pesticides which are used throughout the world to protect grains and rice from rodents and pests ${ }^{1,2}$. ALP exists as yellow to gray granules or powdered solid, formulated as tablets or powder sachets, the lethal dose of ALP is $1-1.5 \mathrm{gm}$. It is cheaper and easily available in market with the brand name of Celphos, Alphos, Quickphos, Phostoxin, Phosphotex. Due to its properties it is being used in the developing countries as an effective grain fumigant ${ }^{2}$.

When it comes in contact with moisture, Phosphine gas is liberated which is very toxic and lethal for the insects, pests and rodents. Pure phosphine gas is colorless and odorless but technical grade phosphine has odor similar to decaying fish or garlic since impurities are

\section{Correspondence}

Dr. Beenish Malik

Demonstrator

Forensic Medicine Department Khyber Medical College,

Peshawar - Pakistan

Email: drbeenishmalik.bm@gmail.com

Cell: +92-345-9153521

Date received: $\quad 01-02-2021$

Date revised: 03-01-2021

Date accepted: 05-05-2021 added to it during the manufacturing ${ }^{2,3-5}$. It is very harmful for human beings due to lethal effects, after oral ingestion of aluminum phosphide it enters into the circulation. Phosphine produces unrestricted organ damage due to cellular hypoxia resulting from its binding to Cytochrome oxidase $^{6}$. The interference with trans-membrane exchange of electrolytes causes acute cardio toxicity and may lead to focal myocardial necrosis. No antidote is available for phosphine gas poisoning and majority of the patients do not survive ${ }^{7,8}$.

Phosphides do not possess any danger to the population if used properly. Accidental and intentional poisoning due to phosphides is dangerous ${ }^{9}$. Many countries use the legal regulation of pesticide trading and utilization in order to prevent deaths associated with the toxic compounds. ALP containing tablets are banned in Iran by the authorities since $2007^{10}$.

In 2008, the number of deaths due to poisoning exceeded the deaths resulting from road traffic accidents and was considered the main cause of death for the first time since 1980. In the past three decades, the death rates due to poisoning increased to almost three folds ${ }^{11}$. The easy availability and toxicity of poisons and the poor health care services in the developing countries shows a high mortality rate of suicidal poisoning $10-20 \%$ even in industrialized countries ${ }^{12}$. In the rural areas of Sri Lanka, pes- 
Prevalence Of Aluminum Phosphide Intoxication Amongst Victims Of Poisoning - Forensic Medicine And Toxicology Registry Data.

ticides poisoning is the most common method of suicide ${ }^{13}$, which is highly lethal ${ }^{14}$ and stands fifth leading cause of death. In Pakistan very little data is available regarding aluminum phosphide poisoning but still it is labelled as the second commonest cause among unintentional injuries in a national health survey of Pakistan ${ }^{15-18}$.

Low survival rate after ALP poisoning and the scale of deaths related to poisoning is on rise in Pakistan 4,7-19, this was the reason to conduct the present study in Forensic Medicine department, KMC, Peshawar, Pakistan. The drive to conduct this study was to define phosphine related deaths in KPK, Pakistan. Our aim to perform the present study was to include the results of toxicological analysis, demography, age group, gender, seasonal variation and trends of ALP poisoning and its prevalence.

\section{MATERIAL AND METHODS}

A Retrospective chart review was conducted at the Department of Forensic Medicine, Khyber Medical College Peshawar, Pakistan, after approval from Institutional research and ethical board, from 1st January 2019 to 31st December 2019. All cases of aluminum phosphide poisoning, including both genders and covering all age groups brought to the department and whose record was available were included in the study. Intoxication due to other poisons and reasons was excluded. External and internal examination of the body was conducted. The internal examination included systematic toxicological analysis performed on liver, stomach contents and blood collected during autopsy. The final opinion of phosphine poisoning was based on history given by relatives, autopsy findings, hospital records and the toxicology reports. The collected data was entered on a pre-designed proforma and the results were summarized as tables and figures after entering the data in SPSS 20.0.

\section{RESULTS}

A total of 940 cases of poisoning were reported to the department for toxicology during 2019, out of which 99 cases were of aluminum phosphide poisoning. Out of the total of 99 cases of aluminum phosphide poisoning $29(29.29 \%)$ were males and $70(70.7 \%)$ were females. Shown in figure-1. The commonly affected age group of victims was between 11-20 years among females and 2130 years among males, making a highest percentage of $36 \%$ and $12 \%$ respectively. Followed by $21-30$ years in females (30\%) and $11-20$ years in males (8\%) given in Table-1.

Majority of the postmortems were conducted during December 13 (13.1\%) followed by October 11 (11.1\%) shown in Figure-2. Highest number of cases were received from Swat that is $33(33.3 \%)$ followed by Kohat $12(12.1 \%)$, detail of other districts is shown in Figure: 3.
Table 1: Age and gender distribution of victims of Aluminum phosphide intoxication

\begin{tabular}{|c|c|c|c|c|c|}
\hline Gender & \multicolumn{5}{|c|}{ Age Group (years) } \\
\hline Years & $11-20$ & $21-30$ & $31-40$ & $\begin{array}{c}\text { Above } \\
40\end{array}$ & Total \\
\hline Male & $\begin{array}{c}8 \\
(8.08 \%)\end{array}$ & $\begin{array}{c}12 \\
(12.12 \%)\end{array}$ & $\begin{array}{c}7 \\
(7.07 \%)\end{array}$ & $\begin{array}{c}2 \\
(2.02 \%)\end{array}$ & 29 \\
\hline Female & $\begin{array}{c}36 \\
(36.36 \%)\end{array}$ & $\begin{array}{c}30 \\
(30.30 \%)\end{array}$ & $\begin{array}{c}4 \\
(4.04 \%)\end{array}$ & 0 & 70 \\
\hline Total & 44 & 42 & 11 & 2 & 99 \\
\hline
\end{tabular}

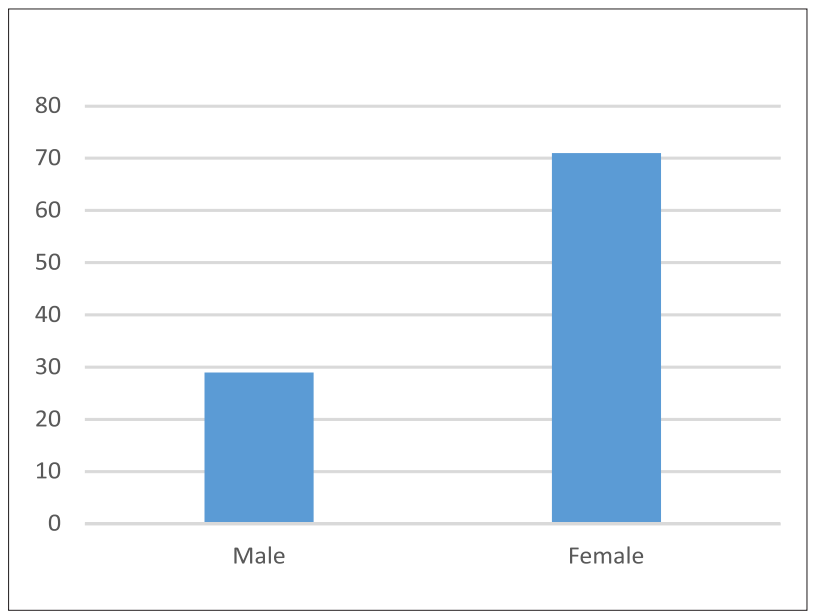

Fig 1: Gender distribution of victims of Aluminum phosphide intoxication

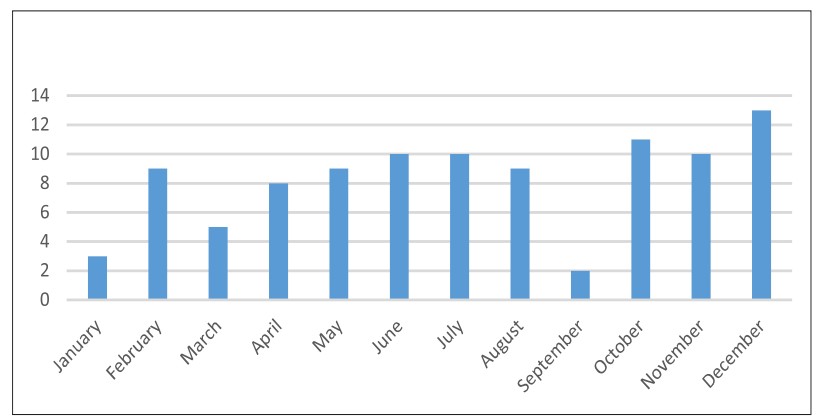

Fig 2: Monthly distribution of victims of Aluminum phosphide intoxication

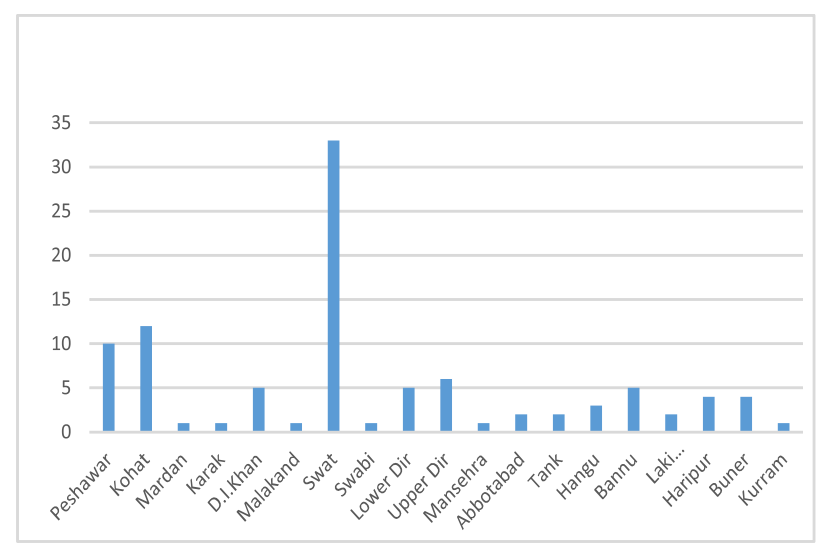

Fig 3: District wise distribution of victims of Aluminum phosphide intoxication 
Prevalence Of Aluminum Phosphide Intoxication Amongst Victims Of Poisoning - Forensic Medicine And Toxicology Registry Data.

\section{DISCUSSION}

Poisoning is a common public health problem all over the world since a long time, occurring all over the world and affecting people of all walk of life. It is reported that almost 700 people die from poisoning everyday all over the world ${ }^{20}$. The incidence of pesticides poisoning in developing countries is reported to be 13-fold higher as compared to the developed countries ${ }^{21,22}$.

The purpose of this study was to inspect phosphine related deaths in KPK. Poisoning as a result of accidental or intentional ingestion of ALP is a common medico-legal issue in Pakistan. In European countries ALP is available only to qualified users, hence suicide by ALP is rare ${ }^{23}$. In the current study phosphine was detected in biological samples with other drugs in Forensic Medicine and Toxicology Department KMC, Peshawar. Phosphine is very volatile and can evaporate from the body during autopsy and due to decontamination, which can give negative results, death due to other poisons can also give negative reports.

The study included 940 victims of poisoning, aluminum phosphide was detected in 99 cases, with 70 female and 29 male. Risk factors maybe underreported, several studies have described a strong association between suicide and mental or physical illness ${ }^{24-27}$. Deaths due to poisoning being more common in females due to the psychological stress, pressure from in-laws and lack of education, which coincides with the studies conducted at China, Japan and Austria. Majority of the victims comprised of younger age groups 21-30 years in males and 11-20 years in females which is in accordance with studies conducted in six major cities of Pakistan ${ }^{28}$. Loss and personal conflicts being the common identifiable life events precipitating suicidal nature. The prevalence of majority of the cases of poisoning was in December in our study, however many cases were received during the hot months of summer, which was also reported in a study conducted in Faisalabad, a major agricultural city of Pakistan ${ }^{28}$.

Adequate law enforcement in the sale and distribution of dangerous drugs and addictive medicines and creating awareness amongst the society especially the young generation through mass media, are one of the few goals to be set on a serious note, which will help reduce the number of deaths due to ALP poisoning. The time interval between poisoning, the dosage and time taken to come to hospital has a significant influence on the outcome of ALP poisoning. The formulation of $3 \mathrm{gm}$ tablets to $10 \mathrm{gm}$ powder in sachets has resulted in a decline in mortality rate in India ${ }^{29}$. The mortality rate depends on the number of survivors reported in the hospital. Negligible legislation for undue propagation of media with minimal implementation results in negative solutions such as suicide or homicide to even minor problems faced by emotionally immature minds.

\section{CONCLUSION}

Aluminum phosphide (wheat pill) is a dangerous and lethal poison and the symptoms progresses quickly to death and there is no antidote for this poison. Pakistan being an agricultural country, with low income and easy availability of wheat pills is the leading cause of ALP. There is a need to substitute safe agents instead of phosphides for preserving grains. Emphasis should be made on the fact that ALP is a lethal poison with low safety and high mortality rate. In our study concluded that intentional poisoning was common amongst young adults. There is insufficient data regarding the exact frequency and therapeutic measures of wheat pill poisoning, therefore largescale studies are required to improve survival from exposure to this dangerous poison. Proper legislation is also required for strict control on the purchase of this lethal drug.

\section{REFERENCES}

1. Gupta S, Ahlawat SK. Aluminum phosphide poisoning-a review. J Toxico: Clin Toxicology. 1995 Jan 1;33(1):19-24.

2. Bumbrah GS, Krishan K, Kanchan T, Sharma M, Sodhi GS. Phosphide poisoning: a review of literature. Foren sci inter. 2012 Jan 10;214(1-3):1-6.

3. Saleki S, Ardalan FA, Javidan-Nejad A. Liver histopathology of fatal phosphine poisoning. Foren sci intern. 2007 Mar 2;166(2-3):190-3.

4. Singh S, Singh D, Wig N, Jit I, Sharma BK. Aluminum phosphide ingestion-a clinico-pathologic study. J Toxico: Clin Toxicology. 1996 Jan 1;34(6):703-6.

5. Shadnia S, Rahimi M, Pajoumand A, Rasouli MH, Abdollahi M. Successful treatment of acute aluminium phosphide poisoning: possible benefit of coconut oil. Human \& experi toxicology. $2005 \mathrm{Apr}$;24(4):215-8.

6. Solgi R, Abdollahi M. Proposing an antidote for poisonous phosphine in view of mitochondrial electrochemistry facts. J Med Hypo and Ideas. 2012 Jan 1;6(1):32-4.

7. Singh SP, Aggarwal AD, Oberoi SS, Aggarwal KK, Thind AS, Bhullar DS et al. Study of poisoning trends in north India-a perspective in relation to world statistics. J foren and legal med. 2013 Jan 1;20(1):14-8.

8. Proudfoot AT. Aluminium and zinc phosphide poisoning. Clini toxicology. 2009 Feb 1;47(2):89-100.

9. Yadav J, Athawal BK, Dubey BP, Yadav VK. Spontaneous ignition in case of celphos poisoning. The Amer $\mathrm{J}$ foren med and patho. 2007 Dec 1;28(4):353-5.

10. Meschi M. Iran Pesticide List. Ministry of Agriculture. 2nd ed. TehranIran. 2007.

11. Warner M, Chen LH, Makuc DM, Anderson RN, Miniño AM. Drug poisoning deaths in the United States, 19802008. NCHS data brief. 2011 Dec 1;81(81):1-8.

12. Ali P, Anwer A, Bashir B, Jabeen R, Haroon H, Makki K. Clinical pattern and outcome of organophosphorus poisoning. J Liaq Uni Med Health Sci. 2012 Jan;11(1):15-8.

13. Knipe DW, Metcalfe C, Fernando R, Pearson M, Konrad- 
Prevalence Of Aluminum Phosphide Intoxication Amongst Victims Of Poisoning - Forensic Medicine And Toxicology Registry Data.

sen F, Eddleston M et al. Suicide in Sri Lanka 1975-2012: age, period and cohort analysis of police and hospital data. BMC public health. 2014 Dec;14(1):1-3.

14. Dawson AH, Eddleston M, Senarathna L, Mohamed F, Gawarammana I, Bowe SJ et al. Acute human lethal toxicity of agricultural pesticides: a prospective cohort study. PLoS Med. 2010 Oct 26;7(10):e1000357.

15. Fatmi Z, Hadden WC, Razzak JA, Qureshi HI, Hyder AA, Pappas G. Incidence, patterns and severity of reported unintentional injuries in Pakistan for persons five years and older: results of the National Health Survey of Pakistan 1990-94. BMC public health. 2007 Dec;7(1):1-7.

16. Khan NU, Khan UR, Feroze A, Khan SA, Ali N, Ejaz K et al. Trends of acute poisoning: 22 years experience from a tertiary care hospital in Karachi, Pakistan. J Pak Med Assoc. 2016;66(10):1237.

17. Hussain AM, Sultan ST. Organophosphorus insecticide poisoning: management in surgical intensive care unit. J Coll Physi Surg-Pak: JCPSP. 2005 Feb 1;15(2):100-2.

18. Khurram M, Mahmood N. Short communication-deliberate self-poisoning: experience at a medical unit. J Pak Med Assoc. 2008;58:455

19. Mehrpour O, Singh S. Rice tablet poisoning: a major concern in Iranian population. Hum experi toxico. 2010 Aug 1;29(8):701.

20. Zine KU, Mohanty AC. Pattern of acute poisoning at Indira Gandhi medical college and hospital, Nagpur. JIAFM. 1998 Apr;20(2):37-9.

21. Käferstein F, Abdussalam M. Food safety in the 21st century. Bulletin of the WHO. 1999;77(4):347.

22. Eddleston M, Phillips MR. Self poisoning with pesticides. Bmj. 2004 Jan 1;328(7430):42-4.

23. Mehrpour $\mathrm{O}$, Jafarzadeh $\mathrm{M}$, Abdollahi M. A systematic review of aluminium phosphide poisoning. Arch Indus Hygie and Toxicology. 2012 Mar 1;63(1):61-73.

24. Dias D, Mendonça MC, Real FC, Vieira DN, Teixeira HM. Suicides in the Centre of Portugal: seven years analysis. Forensic Science International. 2014 Jan 1;234:22-8.
25. Hawton K. van HK. Suicide. Lancet. 2009 Apr 18;373(9672):1372-81.

26. Hegerl U, Wittenburg L, Arensman E, Van Audenhove C, Coyne JC, McDaid D, van der Feltz-Cornelis CM, Gusmão R, Kopp M, Maxwell M, Meise U. Optimizing suicide prevention programs and their implementation in Europe (OSPI Europe): an evidence-based multi-level approach. BMC public health. 2009 Dec;9(1):1-8.

27. Mann JJ, Apter A, Bertolote J, Beautrais A, Currier D, Haas A, Hegerl U, Lonnqvist J, Malone K, Marusic A, Mehlum L. Suicide prevention strategies: a systematic review. Jama. 2005 Oct 26;294(16):2064-74.

28. Khan MM, Naqvi $H$, Thaver D, Prince M. Epidemiology of suicide in Pakistan: determining rates in six cities. Archi suicide rese. 2008 Feb 29;12(2):155-60.

29. Murali R, Bhalla A, Singh D, Singh S. Acute pesticide poisoning: 15 years experience of a large North-West Indian hospital. Clini toxicology. 2009 Jan 1;47(1):35-8.

CONFLICT OF INTEREST: Authors declare no conflict of interest

GRANT SUPPORT AND FINANCIAL DISCLOSURE: NIL

\section{AUTHOR'S CONTRIBUTION}

Following authors have made substantial contributions to the manuscript as under

Malik B: $\quad$ Concept and critical review.

Saleem K: $\quad$ Acquisition and proof reading.

Afridi HK: $\quad$ Analysis and interpretation of data.

Khan R: $\quad$ Final approval.

Zaman MU: Data collection.

Authors agree to be accountable for all aspects of the work in ensuring that questions related to the accuracy or integrity of any part of the work are appropriately investigated and resolved. 